\title{
Chapter 10 \\ Implementation Activities in Design \\ Teams: Opportunities to Demonstrate \\ and Acquire Design Expertise
}

Tjark Huizinga, Nienke Nieveen, and Adam Handelzalts

\section{Introduction}

The implementation of curriculum reform at the school level is a complex process (Fullan, 2007). Too often, reforms are only partially implemented or are implemented in a way that does not represent the reform ideas (e.g., Fullan, 2007; Green, 1980; Stenhouse, 1975; Van den Akker, 2010). One explanation is that oftentimes the key stakeholder, the teacher, is not involved from the early stages of the design process (e.g., Borko, 2004; Darling-Hammond \& McLaughlin, 1995; Fullan, 2007; Stenhouse, 1975). Consequently, teachers lack ownership for the curriculum reform or have a limited understanding of the goals and aim of the reform, because they might feel that they are only implementing the plans of others (Borko, 2004). However, having teachers take on the role of designer is considered to foster teachers' ownership and understanding of the reform (Fullan, 2007, McLaughlin \& Talbert, 2006; Remillard, 1999, 2005; Stenhouse, 1975).

In the Netherlands, teachers are offered the opportunity to take on the role of designer, because teachers have been given 'curricular space' to shape their

\footnotetext{
T. Huizinga $(\triangle)$

Department of Innovative and Effective Education, Saxion University of Applied Sciences,

Enschede, The Netherlands

e-mail: t.huizinga@saxion.nl

N. Nieveen

ELAN Department of Teacher Development, University of Twente,

Enschede, The Netherlands

e-mail: n.m.nieveen@utwente.nl
}

A. Handelzalts

Teacher Education Department, Free University, Amsterdam, The Netherlands

e-mail: a.handelzalts@vu.nl 
school-specific curriculum (Kuiper, Van den Akker, Hooghoff, \& Letschert, 2006; Nieveen \& Kuiper, 2012; Nieveen, Van den Akker, \& Resink, 2010). Various initiatives have provided teachers the opportunity to actively carry out the role of designer of curriculum materials (e.g., VO-Raad, 2014). Studies on these initiatives have reported positive findings on teachers' collaboration in curriculum development. For example, discussing the essence of the renewal and classroom implementation helps teachers to improve their understanding of the reform and fosters their ownership of the reform.

Collaborative design of curriculum materials has been identified as a promising way to foster the design of high quality curriculum materials, to enhance classroom implementation and to promote teachers' learning about design processes (Bakah, Voogt, \& Pieters, 2012; Handelzalts, 2009; Hardré, Ge, \& Thomas, 2006; Fullan, 2007). Collaboration, in what are called Teacher Design Teams [TDTs; teams of teachers who collaboratively (re)design part of their (shared) curriculum (cf. Handelzalts, 2009)], implies that teachers work together throughout the analysis, design, development, implementation and evaluation phases of a new curriculum (also referred to as the ADDIE model, Gustafson \& Branch, 2002).

However, previous attempts suggested that teachers lacked certain knowledge and skills required to fulfil the role of designer (Bakah et al., 2012; Eggleston, 1980; Forbes, 2009; Handelzalts, 2009; Nieveen et al., 2010; Skilbeck, 1984). In order to play a significant role as a curriculum designer and to successfully implement the new curriculum materials in classroom practices, teachers need to have specific knowledge and skills; in particular, they need subject matter knowledge, pedagogical content knowledge and curriculum design expertise (Huizinga, 2009; Nieveen et al., 2010; Nieveen \& Van der Hoeven, 2011; Schwab, 1973). The various categories of expertise required for designing high quality curricula have been comprehensively defined as 'design expertise' (Hardré, 2003; Hardré et al., 2006; Huizinga, 2009; Huizinga, Nieveen, Handelzalts, \& Voogt, 2013; Nieveen \& Van der Hoeven, 2011).

Previous studies have shown that teachers require support during the design process to enhance their design expertise and to tackle design challenges (e.g., Forbes, 2009; Handelzalts, 2009; Huizinga, Handelzalts, Nieveen, \& Voogt, 2014; Kerr, 1981; Nieveen, Handelzalts, Van den Akker, \& Homminga, 2005). Support can help teachers to reflect on their experiences, which can foster their design expertise (Hall \& Hord, 2010; Linder, 2011; Nieveen et al., 2005). Classroom implementation and evaluation seem to offer especially strong opportunities for teacher learning when teachers reflect on their experiences (Guskey, 2000; Voogt et al., 2011). Despite the importance of implementing and evaluating a new curriculum, little is known about how teachers carry out these activities and what expertise they require (e.g., Handelzalts, 2009; Kerr, 1981).

In the current study, TDTs made up of foreign language teachers from secondary schools in the Netherlands were faced with the implementation of the Common European Framework of Reference for Languages [CEFR]. Implementing CEFR requires teachers to apply a skill-oriented approach to learning languages, which also implies that the role of grammar education changes. Furthermore, teachers are 
expected to guide their students in the learning process instead of offering instruction.

This study reports on the TDT's implementation and evaluation activities. These activities are assumed to provide opportunities to enhance teachers' curriculum design expertise. The question that guided this study was: 'What implementation and evaluation activities conducted during the design of a new curriculum provide opportunities for enhancing teachers' curriculum design expertise?' This research question was further divided into three sub-questions: the first aimed at describing the implementation and evaluation activities teachers conducted during classroom implementation; the second question concerned the implementation and evaluation activities in the TDTs and the third focused on teachers' perceptions of the relevance and value of these implementation and evaluation activities for fostering curriculum design expertise.

\section{Curriculum Implementation and Evaluation Expertise}

Curriculum implementation is the process of using the new ideas and materials in classroom practice (Fullan, 2007; Tamir, 2004). Conducting implementation activities is expected to result in classroom practices that represent the original renewal ideas (Hall \& Hord, 2010; Remillard, 2005). However, contextual limitations and personal beliefs, attitudes and expertise may affect to what extent the original renewal ideas are applied in practice by teachers (Remillard, 2005).

Enhancing ownership is essential, because without ownership a curriculum reform will not be implemented or will be implemented in a way that undermines the rationale and goal of the renewal. Therefore, teachers who carry out the role of designers need to know the importance of and how to foster ownership (Kessels \& Plomp, 1999). They need to identify relevant stakeholders, such as the school's management and colleague teachers outside the TDT, and to involve them in the design processes from an early stage (Kessels \& Plomp, 1999). By involving stakeholders, the new curriculum can be aligned with stakeholders' wishes, needs and expectations. Moreover, collaboratively planning the classroom usage of the new curriculum fosters teacher ownership (Penuel, Fishman, Yamaguchi, \& Gallagher, 2007), especially when the teacher role, teacher-student interaction and practical issues are discussed. Additionally, identifying the differences between teachers' current practice and the new curriculum fosters teachers' understanding of the new curriculum.

Managing implementation processes should not start only once the curriculum materials have been designed. Successful curriculum reform requires that the implementation of the curriculum reform is already being managed from the start of the curriculum design process. Carefully planning who will implement what and when helps to guide the design process. The plan describes the goal and scope of the implementation process, and when to involve experts and stakeholders (Richey, Fields, \& Foxon, 2001). TDTs need to monitor the progress of the implementation to identify to what extent the new curriculum is being implemented in practice. 
Reflecting on the teachers' experiences with the new curriculum may result in revising or adjusting the plan.

Sharing experiences throughout the process fosters classroom implementation (Handelzalts, 2009). Piloting newly designed curricula and reflecting on their experiences enhances teachers' understanding of the new curriculum, especially when experiences are shared with colleagues (Hall \& Hord, 2010). Providing curricular programs and exemplary materials helps to improve teachers' understanding of the new curriculum. Exemplary materials that represent the reform ideas shed light on how the reform can be operationalised in practice (Van den Akker \& Voogt, 1994) and might even be directly usable in practice. Finally, guiding teachers to develop a shared understanding of the renewal fosters classroom implementation. Guidance can be offered by demonstrating the new curriculum (e.g., by offering an exemplary lesson or video examples), and through collegial preparation, implementation and reflection on the use of the new curriculum (Hall \& Hord, 2010).

Evaluation refers to the process of determining the worth and merit of a curriculum (Scriven, 1991). Formative evaluations help to identify the aspects that require improvement. Summative evaluations aim to determine the effectiveness of the new curriculum, for example, in terms of student learning (Scriven, 1991). Evaluations can address the product (curriculum) or the design process. Product evaluations identify the consistency, relevance, practicality and effectiveness of the curriculum materials (Nieveen, 2009). Process evaluations address the decisions made, the implementation process and the collaboration within the team.

For planning, structuring and carrying out formative and summative evaluations, teachers must be able to formulate evaluation goals, develop instruments, collect data, analyse the data and interpret the results (Cochran-Smith \& Lytle, 2009; Huizinga, 2009; Schildkamp, Poortman, \& Handelzalts, 2015). It is desirable for teachers to plan and conduct formative and summative evaluations as part of the design process in order to guarantee the quality of the new curriculum. To conduct evaluations, teachers as designers need instruments, either already available or newly developed (Richey et al., 2001). The focus of the evaluation (formativesummative, process-product, phase in the design process) influences the kind of instruments needed (Nieveen, 2009). Teachers as designers need to be able to link the instruments to the evaluation goals.

Quality criteria and activities for evaluating products depend on the stage of the design process. Therefore, teacher as designers are expected to have an understanding of how to assess the consistency, relevance, practicality and effectiveness of the designed curriculum (Nieveen, 2009; Richey et al., 2001). They are expected to assess each quality-related aspect and apply various evaluation methods, since this offers additional insights into the aspects that require improvement. However, previous studies have shown that teachers as designers often do not conduct systematic evaluation activities (Handelzalts, 2009; Kerr, 1981).

Analysing outcomes and improving curriculum. Teacher designers identify the elements of the new curriculum that require improvement. The evaluation data that are gathered need to be analysed and interpreted (Schildkamp et al., 2015). After 
analysing the outcomes, the teacher designers determine how to improve the curriculum and who will make the changes (Richey et al., 2001).

\section{Research Design}

A qualitative case study method was applied (Yin, 2003). Within each case (a TDT), teachers (members of the TDT) used the CEFR-based curriculum their TDT designed in the first stage of the project in their classrooms. All activities conducted by the TDTs and its members to prepare and use the new CEFR-proof curriculum (i.e. language tasks [authentic tasks in which students need to apply the language], assessment rubrics and school-specific adaptations of CEFR regarding teacher role and student activities) in practice are addressed as implementation activities. Evaluation activities relate to activities the TDT and its members conducted to determine the worth and merit of the language tasks and assessments rubrics.

\section{Case Selection}

TDTs were selected from the CEFR-project who (1) integrated CEFR in their foreign language curriculum, (2) created language tasks (and assessment rubrics) during the analysis and design stage, and (3) planned to use the new curriculum in their classrooms. Based on these criteria, three cases (out of 15) were selected for this study: Plato, Thales and Othello. They varied in the number of teachers involved in the TDT (5-16 teachers). All participating TDTs received tailored support from different facilitators, who were employed at the Netherlands Institute for Curriculum Development. The facilitators were both curriculum developers and former language teachers. The facilitators were familiar with CEFR and experienced in supporting TDTs. Othello's TDT was part of a greater community of schools and received guidance from two facilitators.

\section{Data Collection}

Five instruments and one artefact were used. All instruments were discussed in the research team to warrant content validity (Yin, 2003).

Storyline method. The storyline method helps teachers reflect on processes. Based on a guiding question, the teachers draw a line in a coordinate system. The $\mathrm{x}$-axis represents the time (in months) and the $\mathrm{y}$-axis represents the teachers' experiences, on a five-point scale ranging from very negative (1) to very positive (5). Teachers individually drew a storyline and afterwards each teacher individually clarified (changes in) the line (Beijaard, Van Driel, \& Verloop, 1999; Handelzalts, 
2009). The guiding questions in this study were: "How did you experience the design process as conducted within the TDT?" and "How did you experience the classroom implementation of the CEFR-proof curriculum?" While introducing the storyline method, the researcher emphasised reflecting on implementation and evaluation activities. The teachers received an overview of the implementation and evaluation activities that had been conducted. The storyline method was expanded with a semistructured group interview to identify support offered to the TDTs (Huizinga, Handelzalts, Nieveen, \& Voogt, 2015). Transcriptions and summaries were made and summaries were sent to the teachers for member checking (Merriam, 1988).

Observation checklist TDT meetings. The observation checklist of Huizinga et al. (2015) was adapted to identify TDTs' implementation and evaluation activities. The checklist addressed the activities conducted, teachers' reactions during these activities, teachers' questions raised during the meetings (and facilitators' response if applicable), concerns articulated that were related to the activities, and the contextual setting in which the meeting was organised.

Semi-structured interview facilitator. A semi-structured interview with the facilitator was administered to identify the characteristics of the support offered to the TDTs during the implementation and evaluation phases. These insights were used to identify and triangulate the TDTs' implementation and evaluation activities.

Observation checklist classroom observation. An observation checklist was developed, which included the lesson activities, teacher's role during the lesson activities, student-teacher interaction and the context in which the lesson was conducted.

Semi-structured interview teachers. The interview addressed teachers' experiences of the observed lesson, to what extent the observed lesson could be compared with other CEFR lessons and the (need for) support to carry out implementation and evaluation activities.

Language task. The language tasks in the observed lessons were analysed to identify the intended curriculum (e.g., CEFR proficiency level, learning activities). These insights were compared with the classroom observations to identify when changes were made by the teachers while using the language tasks in practice.

The data collected data used to (1) re-construct the TDTs' implementation and evaluation activities, (2) determine teachers' experiences of the TDTs' implementation and evaluation activities, and (3) determine the implementation and evaluation activities in teachers' own classrooms, and determine teachers' experiences with implementation and evaluation activities in their own classroom.

\section{Data Analysis}

All qualitative data were analysed using 'a priori' coding (Strauss \& Corbin, 1998). This data analysis technique prescribes that a codebook is based on the theoretical framework. While analysing, the codes are linked to (parts of) the data. Inductive 
coding was applied to find additional themes related to the implementation and evaluation process and teachers' experiences.

The first author took the lead in the coding process. Quotes were selected and codes were assigned. First, quotes were related to TDT or classroom activities and the researcher identified whether the quote illustrated teachers' experiences with the activities (level-1 code). For example, the quote "we have worked on it [implementation] [during the support meeting with all foreign language teachers]. Positive memories about it." was assigned the code "TDT-Experience-Implementation". Second, the specific characteristic of the activity was identified (level-2 code).

Table 10.1 Section of the final codebook

\begin{tabular}{|c|c|c|}
\hline Level 1 code & Description of the code & Example quote [data source] \\
\hline $\begin{array}{l}\text { TDT- } \\
\text { implementation }\end{array}$ & $\begin{array}{l}\text { Implementation activity } \\
\text { conducted by TDT (e.g., } \\
\text { preparation for using } \\
\text { materials in practice) }\end{array}$ & $\begin{array}{l}\text { 'Then [during schoolwide support day], }[\ldots] \\
\text { I experienced that as positive, because our } \\
\text { colleagues outside the TDT responded } \\
\text { enthusiastically }[. . .] \text { We made some } \\
\text { agreements [about using CEFR]" [storyline } \\
\text { reflection] }\end{array}$ \\
\hline TDT-evaluation & $\begin{array}{l}\text { Evaluation activity } \\
\text { conducted by TDT (e.g., } \\
\text { reflecting on use in } \\
\text { classroom) }\end{array}$ & $\begin{array}{l}\text { "I used existing [evaluation] formats that we } \\
\text { have developed for a course about } \\
\text { curriculum design. I changed these formats } \\
\text { completely to align them to the vision of the } \\
\text { school and discussed it with the teachers. } \\
\text { The teachers tested the instrument in } \\
\text { practice" [interview facilitator] }\end{array}$ \\
\hline $\begin{array}{l}\text { TDT-experience- } \\
\text { implementation }\end{array}$ & $\begin{array}{l}\text { TDT member experience } \\
\text { of conducted activity } \\
\text { related to using CEFR in } \\
\text { the classroom }\end{array}$ & $\begin{array}{l}\text { "If you look at all our meetings, the overall } \\
\text { line is clear. Each individual meeting was } \\
\text { useful, especially when you receive } \\
\text { examples of how to do it in practice" } \\
\text { [storyline reflection] }\end{array}$ \\
\hline $\begin{array}{l}\text { TDT-experience- } \\
\text { evaluation }\end{array}$ & $\begin{array}{l}\text { TDT member experience } \\
\text { of activity conducted } \\
\text { related to evaluating the } \\
\text { use of CEFR in the } \\
\text { classroom }\end{array}$ & $\begin{array}{l}\text { 'I was sitting next to my colleague [...], I } \\
\text { wrote a reflection on the language tasks, } \\
\text { summing up 'check this, look at that'. That's } \\
\text { the way we provide feedback, just-in-time or } \\
\text { if you experience difficulties' [storyline } \\
\text { reflection] }\end{array}$ \\
\hline $\begin{array}{l}\text { Classroom- } \\
\text { implementation }\end{array}$ & $\begin{array}{l}\text { Teachers' individual use of } \\
\text { CEFR in the classroom }\end{array}$ & $\begin{array}{l}\text { 'The teacher starts the lesson in French. She } \\
\text { explains that if students have difficulties in } \\
\text { understanding the teachers, she [teacher] } \\
\text { will provide the translation. [classroom } \\
\text { observation] }\end{array}$ \\
\hline $\begin{array}{l}\text { Classroom- } \\
\text { evaluation }\end{array}$ & $\begin{array}{l}\text { Evaluation activities } \\
\text { conducted by individual } \\
\text { teachers }\end{array}$ & $\begin{array}{l}\text { 'During my own evaluation, I ask myself the } \\
\text { question 'what went wrong' and 'what did } \\
\text { not go as I expected'. I discuss this with my } \\
\text { students, because they might experience it } \\
\text { defiantly.' [Interview teacher] }\end{array}$ \\
\hline
\end{tabular}


Table 10.1 (continued)

\begin{tabular}{|c|c|c|}
\hline Level 1 code & Description of the code & Example quote [data source] \\
\hline $\begin{array}{l}\text { Classroom- } \\
\text { experience- } \\
\text { implementation }\end{array}$ & $\begin{array}{l}\text { Teachers' personal } \\
\text { experience of using CEFR } \\
\text { in his/her own classroom }\end{array}$ & $\begin{array}{l}\text { 'The overall experience of today's lessons } \\
\text { also depends on the students' final products. } \\
\text { There were a lot of practical questions, [...], } \\
\text { which might be the case because the } \\
\text { language tasks were too textual for these } \\
\text { students.' [Interview teacher] }\end{array}$ \\
\hline $\begin{array}{l}\text { Classroom- } \\
\text { experience- } \\
\text { evaluation }\end{array}$ & $\begin{array}{l}\text { Teachers' personal } \\
\text { experience of carrying out } \\
\text { evaluations related to the } \\
\text { use CEFR in his/her own } \\
\text { classroom }\end{array}$ & $\begin{array}{l}\text { 'At the end of the lesson I've asked for } \\
\text { feedback, normally I don't ask for written } \\
\text { feedback, but it requires students to reflect } \\
\text { on the task they carried out.' [Interview } \\
\text { teacher] }\end{array}$ \\
\hline $\begin{array}{l}\text { Level } 2 \text { code } \\
\text { [example for } \\
\text { 'TDT- } \\
\text { implementation'] }\end{array}$ & Description of the code & Example quote [data source] \\
\hline $\begin{array}{l}\text { Enhancing } \\
\text { ownership }\end{array}$ & $\begin{array}{l}\text { Conducting activities to } \\
\text { enhance ownership (e.g., } \\
\text { collaborative preparation } \\
\text { for classroom use, } \\
\text { involving stakeholders in } \\
\text { design) }\end{array}$ & $\begin{array}{l}\text { 'For English, } 16 \text { teachers were at the } \\
\text { meeting. The TDT started with a discussion } \\
\text { about the examination program. They } \\
\text { discussed to what extent all programs need } \\
\text { to be similar. [TDT observation] }\end{array}$ \\
\hline $\begin{array}{l}\text { Managing } \\
\text { implementation } \\
\text { process }\end{array}$ & $\begin{array}{l}\text { Conducting activities } \\
\text { required for process } \\
\text { management (e.g., } \\
\text { developing plan, } \\
\text { monitoring progress) }\end{array}$ & $\begin{array}{l}\text { From one of the locations, the expectation } \\
\text { was that more support would be provided } \\
\text { from the school's management and that } \\
\text { more schoolwide support meetings were } \\
\text { organised. The teachers argued that using } \\
\text { CEFR in practice requires additional } \\
\text { professional development activities. [TDT } \\
\text { observation] }\end{array}$ \\
\hline Sharing experiences & $\begin{array}{l}\text { Conducting activities in } \\
\text { which experiences with the } \\
\text { new curriculum are shared } \\
\text { (e.g.,the new curriculum, } \\
\text { providing video examples) }\end{array}$ & $\begin{array}{l}\text { The French teacher explains that the } \\
\text { experienced resistance was also related to } \\
\text { the fact that students are not used to working } \\
\text { with language tasks. In the last year, she } \\
\text { used several language tasks. Her students } \\
\text { appreciate them more than regular lessons. } \\
\text { [group discussion during TDT observation] }\end{array}$ \\
\hline
\end{tabular}

The sample quote above, for example, was assigned the level-2 code "enhancing ownership". Throughout the coding process, the application of codes was discussed in the research team until consensus was achieved. In Table 10.1 a section of the final codebook is provided, in which the codes, and a description and example for both the level-1 codes and the level-2 codes are included. 


\section{Main Findings}

This study was undertaken to identify what implementation and evaluation activities conducted by TDTs provide opportunities to enhance teachers' curriculum design expertise. Therefore, implementation and evaluation activities that were conducted were identified and teachers reflected on their experiences with these activities, as initiated during classroom implementation and by TDTs. These insights illustrate which implementation and evaluation activities teachers valued and found relevant for their process.

\section{Teachers' Classroom Implementation and Evaluation Activities}

The activities carried out in and by the TDTs were intended to prepare the teachers to implement the new curriculum in the classroom and to evaluate the lessons. Classroom observations revealed great variation in classroom implementation across teachers within and between the different TDTs. The skill-oriented approach for learning languages required students to actively use the foreign language. The language tasks that were developed partly prescribed to what extent the foreign language had to be spoken by teachers and students, which was the case for Plato and Othello. The language village task, which was used by Othello, required both teachers and students to use the foreign language, since the conversations between them were the core of the task. Integrating the skill-oriented approach also required teachers to fulfil the role of coach. The results illustrated that coaching differed across teachers both within and between cases. In Thales, teachers offered a detailed introduction in which the entire language task was clarified for the students. In contrast, in Plato and Othello, teachers coached their learners by providing just-in-time guidance required to complete the tasks.

Teachers' reflections revealed that classroom implementation and evaluation were affected by their understanding of CEFR, the new pedagogy and especially the teacher role. Plato's and Othello's teachers had various questions about their role and wondered whether they had offered too much guidance. Although various discussions within the TDTs had addressed the pedagogy and exemplary materials and videos were offered (cf. Ball \& Cohen, 1996), the results of this study suggest that only discussing and observing a new pedagogical approach is too limited to acquire the required expertise (cf. Voogt et al., 2011). Therefore, it seems essential that additional opportunities in which teachers can apply the new pedagogical approach and use the new curriculum are necessary to improve their pedagogical skills and develop confidence in the new approach.

Teachers in all three TDTs discussed the language tasks with their fellow colleagues during and outside TDT meetings. However, collegial feedback appeared not to be enough to develop high quality language tasks, emphasizing the need for piloting the language tasks in teaching practice (cf. Handelzalts, 2009). Furthermore, 
the results illustrated that teachers hardly involved students in their evaluations, suggesting that teachers need to learn how to involve their learners with the aim of improving the language tasks.

\section{TDTs' Implementation and Evaluation Activities and Corresponding Experiences}

Table 10.2 provides the results of the cross-case analysis of the three TDTS. Each TDT organised its own implementation process, implying that the type and intensity of the activities varied across the three TDTs. All TDTs conducted activities in which experiences were shared, for example, though exemplary materials or video examples. How experiences were shared depended on the TDT and the context in which the TDT was operating. Consequently, the opportunities for conducting and experiencing specific activities differed. In Plato, not all foreign language teachers were part of the TDT. Therefore, Plato's TDT had to conduct additional activities to enhance ownership, for example, by discussing the new pedagogy with their colleagues and providing exemplary materials. In Thales and Othello teachers shared experiences during collegial meetings by illustrating how they had used a particular language task in practice. Teachers' reflections revealed that they acquired new ideas on how to use the new curriculum, which fostered its implementation (cf. Anto, 2013; Huizinga et al., 2015). However, teachers also indicated struggling with translating the curriculum reform to their classroom practices and they had concerns about the pedagogy. In Thales and Othello all foreign language teachers were involved in the TDT; therefore, managing and structuring the implementation

Table 10.2 TDT's implementation and evaluation expertise

\begin{tabular}{l|l|l|l}
\hline Characteristics & Plato & Thales & Othello \\
\hline Duration of process & 16 months & 9 months & 9 months \\
\hline Implementation knowledge and skills & & & \\
\hline Enhancing ownership & + & + & + \\
\hline Managing implementation processes & - & $+/-$ & $+/-$ \\
\hline Sharing experiences & + & + & + \\
\hline Evaluation knowledge and skills & & & \\
\hline Planning, structuring and carrying out evaluations & $+/-$ planning & - & + planning \\
\cline { 2 - 2 } & $+/-$ & & $+/-$ \\
& structuring & & structuring \\
\hline & + carrying out & & + carrying out \\
\hline Quality criteria and activities for evaluating products & $+/-$ & - & $+/-$ \\
\hline Analysing outcomes and improving curriculum & + & - & + \\
\hline
\end{tabular}

Note: + knowledge and skills sufficient, various activities carried out by TDT; +/- knowledge and skills limited, some activities carried out by TDT; - knowledge and skills insufficient, no activities carried out by TDT 
process needed explicit attention. This explicit attention also seems to provide opportunities to enhance curriculum design expertise.

Each TDT also organised their own evaluation activities, which resulted in unplanned and unstructured evaluations in Plato and Othello. These evaluations provided the TDTs with insights into the practical quality of the curriculum: alignment with students' prior knowledge and internal consistency of the design language. In Thales no evaluations were conducted, despite the fact that they received external support regarding the role of evaluations and how to conduct them. The reason might be that the support concerning evaluation was not offered when the teachers needed it (cf. Handelzalts, 2009).

Based on the implementation activities carried out and the teachers' reflections, it seemed that the expertise within TDTs was adequate to foster the implementation process. Furthermore, evaluation activities closely related to teachers' classroom practice, such as piloting assessment rubrics and language tasks, were especially valued by teachers (cf. Handelzalts, 2009; Huizinga et al., 2014, 2015). Teachers felt that collegial feedback and presenting their TDT's progress to other TDTs made them aware of what they had achieved (cf. Hall \& Hord, 2010), but teachers did not indicate that that this fostered the implementation and evaluation process. Based on the evaluation activities carried out, it seems that teachers' expertise in this domain was limited (cf. Handelzalts, 2009; Kerr, 1981).

\section{Conclusion and Discussion}

Teachers are increasingly involved in the design of a curriculum reform (Forbes, 2009; Handelzalts, 2009; Law \& Nieveen, 2010; Lohuis, Huizinga, 't Mannetje, \& Gellevij, 2016). Although most teachers have experience in adapting existing materials to specific needs (e.g., Remillard, 1999, 2005), they have less experience in designing curriculum reform at the subject level. Despite this lack of experience, this study showed that teachers as designers initiate various implementation strategies, but rarely conduct evaluation activities.

During classroom implementation teachers used the developed curriculum materials in practice, but did little evaluation of the lessons and the materials used. Furthermore, the teachers in the TDTs experienced how important it is to enhance their colleagues' ownership for the materials. They initiated various implementation activities to develop their colleagues' ownership. They collaboratively prepared for classroom implementation, shared experiences of their own classroom implementation with colleagues outside the TDT, offered exemplary materials and discussed video-recordings of lessons. The observations revealed that the TDTs in this study conducted few evaluation activities. The evaluations they did perform were rather unprepared, unstructured and emphasised the practical quality of the new curriculum materials, but focused less on the students' learning. This led to the conclusion that teachers in TDTs need additional support to conduct evaluation activities. 
Teachers as designers must deal with design challenges when they design curriculum materials in teams. These challenges not only consist of the decisions that have to be made about the materials themselves, but also concern how to organize the implementation process. In order to deal with these challenges, teachers need to find, select and apply relevant strategies to enhance the design and implementation process. However, most teachers have limited prior experience in curriculum design and struggle with finding the relevant strategies to overcome the challenges experienced. The results of this study underline that teacher involvement in the design of concrete curriculum materials through TDTs provides teachers with various opportunities to learn about curriculum design and the intended curriculum reform. As previous studies have illustrated, in TDTs teachers learn to make decisions about the curriculum materials and the curriculum design process (Handelzalts, 2009; Huizinga et al., 2015). This study also underlined that teachers experience the influence of their choices on classroom implementation. The potential of carrying out design activities for developing teachers' curriculum design expertise is not yet fully utilised by TDTs, because some design activities, such as evaluation, are rarely conducted by TDTs.

The results of this study further illustrate that working in TDTs offers opportunities to practice and acquire implementation and evaluation skills (cf. Ben-Peretz, 1990; Voogt et al., 2011). The specific activities conducted by the teams of teachers provide opportunities for teacher learning, both about the reform framework and about the implementation and evaluation stages of curriculum design (cf. Penuel et al. 2007; Voogt et al., 2011). The findings underpin the importance of reflecting on the activities conducted as well as sharing these insights with colleagues (Hall \& Hord, 2010; Voogt et al., 2011). Explicit attention for evaluation expertise is needed, since teachers seem to develop this little while working in TDTs (cf. Handelzalts, 2009; Hoogveld, 2003; Kerr, 1981).

This study shed light on the implementation and evaluation activities carried out by teachers in TDTs and during classroom enactment of the new materials. First, the study shows that the members of the TDT need to understand the essence of ownership and how to foster it (cf. Kessels \& Plomp, 1999), especially when not all their colleagues are involved in the TDT. TDTs can achieve this by involving their colleagues at specific points during the design process, as was the case in Plato, where colleagues outside the TDT were involved during support meetings. Second, in contrast to Richey et al. (2001), managing the implementation process is not necessarily an expert-designer skill, as this study found that the TDT's coordinators had basic planning and monitoring skills. Third, TDT activities that were closely related to (changing) classroom practice were valued by teachers and seemed to offer opportunities for learning. Previous studies have suggested that supporting teachers in reflecting on their experiences helps to deepen their understanding of the activities conducted (e.g., Anto, 2013; Huizinga et al., 2015). Finally, classroom implementation helped to deepen teachers' understanding of the new curriculum, especially when they shared experiences with fellow teachers and had to explain what they did during classroom implementation (cf. Hall \& Hord, 2010). 
Kirkpatrick (1979) argued that positive experiences and beliefs illustrate which activities are necessary for teacher learning. In this study, the implementation and evaluation activities that were conducted together with teachers' reflections on these activities were used to identify what opportunities TDTs provide for enhancing curriculum design expertise. Therefore, the storyline method was applied to let teachers reflect on their process and the decisions made to conduct specific activities. It was assumed that when teachers did not conduct and did not indicate why certain activities were not conducted, they lacked the design expertise for implementation and evaluation. However, teachers might have that expertise, but did not reflect or demonstrate it during the process.

The knowledge and skills needed for implementation and evaluation were derived from overviews developed to describe the expertise of instructional and curriculum designers. Although in previous studies these knowledge and skills were translated to fit teachers and the design tasks they face (Huizinga, 2009; Huizinga et al., 2014; Nieveen \& Van der Hoeven, 2011), the results of this study suggest that some of the identified knowledge and skills for implementation and evaluation might not be developed through participation in TDTs. Teachers might not develop the expertise to plan and structure evaluations while working in TDTs and, therefore, need just-in-time support to acquire this expertise (cf. Handelzalts, 2009). This study also illustrated that support which is not offered just-in-time will not result in acquiring the necessary expertise, as was the case in Thales.

The results of this study showed that without specific just-in-time support, TDTs initialise various activities to foster the implementation, such as enhancing ownership for the new curriculum (e.g., through involving colleagues in design activities) and sharing experience with teachers within and outside the TDT (e.g., by offering exemplary materials and videos). However, without support TDTs rarely plan and conduct (structured) evaluation to assess the quality of the designed curriculum (cf. Handelzalts, 2009; Kerr, 1981). The only evaluation activities by TDTs focused on the practical aspects of the curriculum (e.g., feasible within the given time, do the students understand and learn from the language task). They did not evaluate how the materials were used in the classroom or the effects of the materials on students. In some cases, students were involved in the evaluation activities. Since most evaluation activities were based on teachers' (personal) experiences to assess the quality, it seems that teachers in TDTs need additional expertise to conduct a wider variety of evaluation activities to assess the quality of the new curriculum. This additional expertise can be fostered by providing just-in-time support aligned with teachers' prior knowledge and experiences. 


\section{References}

Anto, A. G. (2013). Collaborative teacher professional development in Ethiopian higher education: The case of communicative language teaching (Doctoral dissertation). Enschede, The Netherlands: University of Twente.

Bakah, M. A. B., Voogt, J. M., \& Pieters, J. M. (2012). Advancing perspectives of sustainability and large-scale implementation of design teams in Ghana's polytechnics: Issues and opportunities. International Journal of Educational Development, 32, 787-796.

Ball, D., \& Cohen, D. (1996). Reform by the book: What is - or might be - the role of curriculum materials in teacher learning and instructional reform? Educational Researcher, 25(9), 6-8. 14.

Beijaard, D., Van Driel, J., \& Verloop, N. (1999). Evaluation of story-line methodology in research on teachers' practical knowledge. Studies in Educational Evaluation, 25, 47-62.

Ben-Peretz, M. (1990). The teacher-curriculum encounter: Freeing teachers from the tyranny of texts. New York: State University of New York Press.

Borko, H. (2004). Professional development and teacher learning: Mapping the terrain. Educational Researcher, 33(8), 3-15.

Cochran-Smith, M., \& Lytle, S. L. (2009). Inquiry as stance: Practitioner research for the next generation. New York: Teacher College Press.

Darling-Hammond, L., \& McLaughlin, M. W. (1995). Policies that support professional development in an era of reform. Phi Delta Kappan, 76(8), 597-604.

Eggleston, J. (1980). School-based curriculum development in Britain: A collection of case studies. London: Routledge \& Kegan Paul.

Forbes, C. T. (2009). Preservice elementary teachers' development of pedagogical design capacity for inquiry: An activity-theoretical perspective (Doctoral dissertation). Ann Arbor, MI: University of Michigan.

Fullan, M. G. (2007). The new meaning of educational change (4th ed.). New York: Teachers College Press.

Green, E. L. (1980). The independent learning in science model of school-based curriculum development. In J. Eggleston (Ed.), School-based curriculum development in Britain: A collection of case studies (pp. 14-40). London: Routledge \& Kegan Paul.

Guskey, T. R. (2000). Evaluating professional development. Thousand Oaks, CA: Corwin Press.

Gustafson, K. L., \& Branch, R. M. (2002). Survey of instructional development models (4th ed.). Syracuse, NY: Syracuse University.

Hall, G. E., \& Hord, S. M. (2010). Implementing change: Patterns, principles, and potholes (3rd ed.). New York: Pearson College Division.

Handelzalts, A. (2009). Collaborative curriculum design in teacher design teams (Doctoral dissertation). Enschede, The Netherlands: University of Twente.

Hardré, P. L. (2003). The effects of instructional training on university teaching assistants. Performance Improvement Quarterly, 16(4), 23-39.

Hardré, P. L., Ge, X., \& Thomas, M. K. (2006). An investigation of development toward instructional design expertise. Performance Improvement Quarterly, 19(4), 63-90.

Hoogveld, A. W. M. (2003). The teacher as designer of competency-based education (Doctoral dissertation). Heerlen, The Netherlands: Open University.

Huizinga, T. (2009). Op weg naar een instrument voor het meten van docentcompetenties voor het ontwikkelen van curricula [Towards an instrument to measure teachers' competencies for the development of curricula; Master's thesis]. Enschede, The Netherlands: University of Twente.

Huizinga, T., Nieveen, N., Handelzalts, A., \& Voogt, J. M. (2013). Ondersteuning op curriculumontwikkelexpertise van docentontwikkelteams [Support to teacher design teams to foster teachers' curriculum design expertise]. Pedagogische Studiën, 90(3), 4-20.

Huizinga, T., Handelzalts, A., Nieveen, N., \& Voogt, J. M. (2014). Teacher involvement in curriculum design: Need for support to enhance teachers' design expertise. Journal of Curriculum Studies, 46(1), 33-57. 
Huizinga, T., Handelzalts, A., Nieveen, N., \& Voogt, J. M. (2015). Fostering teachers' design expertise in teacher design teams: Conducive design and support activities. The Curriculum Journal, 26(1), 137-163.

Kerr, S. T. (1981). How teachers design their materials: Implications for instructional design. Instructional Science, 10, 363-378.

Kessels, J. W. M., \& Plomp, T. (1999). A systematic and relational approach to obtaining curriculum consistency in corporate education. Journal of Curriculum Studies, 31(6), 679-709.

Kirkpatrick, D. L. (1979). Techniques for evaluating training programs. Training and Development Journal. June, 178-192.

Kuiper, W., Van den Akker, J., Hooghoff, H., \& Letschert, J. (2006). Curriculum policy and school practice in a European comparative perspective. In J. Letschert (Ed.), Curriculum development re-invented (Proceedings of the invitational conference on the occasion of the 30 years SLO 1975-2005. Leiden, the Netherlands, 7-9 December 2005) (pp. 56-77). Enschede, The Netherlands: SLO.

Law, E. H., \& Nieveen, N. (2010). Schools as curriculum agencies: Asian and European perspectives on school-based curriculum development. Rotterdam: Sense Publishers.

Linder, S. M. (2011). The facilitator's role in elementary mathematics professional development. Mathematics Teacher Education and Development, 13(2), 44-66.

Lohuis, A. H., Huizinga, T., 't Mannetje, J. E. M. M., Gellevij, M. R. M. (2016). Improving support to Teacher Design Teams to foster teachers' design expertise and blended learning expertise. Paper presented during the EAPRIL conference, Porto, Portugal.

McLaughlin, M. W., \& Talbert, J. E. (2006). Building school-based teacher learning communities. Professional strategies to improve student achievement. New York: Teachers College Press.

Merriam, S. B. (1988). Case study research in education. San Francisco: Jossey-Bass.

Nieveen, N. (2009). Formative evaluation in educational design research. In T. Plomp \& N. Nieveen (Eds.), An introduction to educational design research (pp. 89-102). Enschede, The Netherlands: SLO.

Nieveen, N., \& Kuiper, W. (2012). Balancing curriculum freedom and regulation in the Netherlands. European Educational Research Journal, 11(3), 357-368.

Nieveen, N., \& Van der Hoeven, M. (2011). Building the curricular capacity of teachers: Insights from the Netherlands. In P. Picard \& L. Ria (Eds.), Beginning teachers: A challenge for educational systems - CIDREE yearbook 2011 (pp. 49-64). Lyon, France: ENS de Lyon, Institut français de l'Éducation.

Nieveen, N., Handelzalts, A., Van den Akker, J. J. H., \& Homminga, S. (2005). Teacher design teams: A scenario for school-based curriculum innovation. Paper presented at the ECER, Dublin, Ireland.

Nieveen, N., Van den Akker, J. J. H., \& Resink, F. (2010). Framing and supporting school-based curriculum development in the Netherlands. In E. H. Law \& N. Nieveen (Eds.), Schools as curriculum agencies: Asian and European perspectives on school-based curriculum development (pp. 273-283). Rotterdam, The Netherlands: Sense Publishers.

Penuel, W. R., Fishman, B. J., Yamaguchi, R., \& Gallagher, L. P. (2007). What makes professional development effective? Strategies that foster curriculum implementation. American Educational Research Journal, 44(4), 921-958.

Remillard, J. T. (1999). Curriculum materials in mathematics education reform: A framework for examining teachers' curriculum development. Curriculum Inquiry, 29, 315-342.

Remillard, J. T. (2005). Examining key concepts in research on teachers' use of mathematics curricula. Review of Educational Research, 75(2), 211-246.

Richey, R. C., Fields, D. C., \& Foxon, M. (2001). Instructional design competences: The standards (3rd ed.). Syracuse, NY: Clearinghouse on Information \& Technology Syracuse University.

Schildkamp, K., Poortman, C. L., \& Handelzalts, A. (2015). Data teams for school improvement. School Effectiveness and School Improvement, 27(2), 228-254.

Schwab, J. J. (1973). The practical 3: Translation into curriculum. School Review, 81(4), 501-522.

Scriven, M. (1991). Evaluation thesaurus (4th ed.). Newbury Park, CA: Sage. 
Skilbeck, M. (1984). School-based curriculum development. London: Harper \& Row.

Stenhouse, L. (1975). An introduction to curriculum research and development. London: Heinemann Educational Books.

Strauss, A., \& Corbin, J. (1998). Basics of qualitative research techniques and procedures for developing grounded theory (2nd ed.). Thousand Oaks, CA: Sage Publications.

Tamir, P. (2004). Curriculum implementation revisited. Journal of Curriculum Studies, 36(3), 281-294.

Van den Akker, J. J. H. (2010). Building bridges: How research may improve curriculum policies and classroom practices. In S. Stoney (Ed.), Beyond Lisbon 2010: Perspectives from research and development for education policy in Europe (CIDREE Yearbook 2010) (pp. 175-195). Slough, UK: NFER.

Van den Akker, J. J. H., \& Voogt, J. (1994). The use of innovation and practice profiles in the evaluation of curriculum implementation. Studies in Educational Evaluation, 20, 503-512.

Voogt, J., Westbroek, H., Handelzalts, A., Walraven, A., McKenney, S., Pieters, J., et al. (2011). Teacher learning in collaborative curriculum design. Teacher and Teaching Education, 27(8), $1235-1244$.

VO-Raad. (2014). Klaar voor de toekomst! Samen werken aan onderwijskwaliteit. Sector akkoord VO 2014-2017 [Ready for the future! Collaborating on the quality of education. Sectoral agreement secondary education 2014-2017]. Den Haag, The Netherlands: VO-Raad.

Yin, R. K. (2003). Case study research: Design and methods (3rd ed.). Thousand Oaks, CA: Sage Publications.

Open Access This chapter is licensed under the terms of the Creative Commons Attribution 4.0 International License (http://creativecommons.org/licenses/by/4.0/), which permits use, sharing, adaptation, distribution and reproduction in any medium or format, as long as you give appropriate credit to the original author(s) and the source, provide a link to the Creative Commons licence and indicate if changes were made.

The images or other third party material in this chapter are included in the chapter's Creative Commons licence, unless indicated otherwise in a credit line to the material. If material is not included in the chapter's Creative Commons licence and your intended use is not permitted by statutory regulation or exceeds the permitted use, you will need to obtain permission directly from the copyright holder.

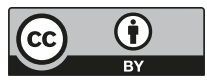

